\title{
Фізична терапія дітей шкільного віку з порушенням постави у посднанні з захворюванням на гастрит
}

\author{
ДВНЗ «Ужгородський національний університет», м. Ужгород, Україна
}

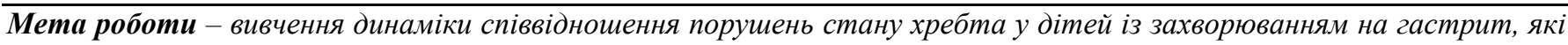
проходили оздоровчий курс на базі санаторію "Поляна".

Завдання - визначення прийомів та засобів фізичної реабілітації дітей шкільного віку, у яких порушення постави поєднані з захворюванням на гастрит. Використані такі методи дослідження, як тести на виявлення порушень постави, проба Руф'є, клінічні обстеження на початку і в кінці проведеного відновного лікування. Вивчався вплив комплексного підходу до реабілітації дітей, спостережено позитивні зміни з боку обох патологій. Обстежено 50 дітей шкільного віку, у яких захворювання на гастрит поєднувалося з сутулістю, плоскою спиною, сколіотичною поставою, сколіозом. Під впливом реабілітачійних заходів простежуються позитивні зміни як у клінічних проявах основного захворювання, так і в корекиії постави.

Ключові слова: постава, гастрит, фізична реабілітачія, масаж, діти, проба Руф'є.
\end{abstract}

\section{Вступ}

$\Pi$ ротягом останніх років спостерігається тенденція до загального погіршення стану здоров’я населення України, насамперед дітей. Вчені пов’язують цю тенденцію зі збільшенням захворюваності на хвороби травного тракту, а також слабкими фізичними навантаженнями. Ю.В.Белоусов, М.Ф.Денисова стверджують, що частота дитячої гастроентерологічної патології коливається в межах 130-180\%, причому відмічається тенденція до збільшення цих показників $[2,3]$.

Однією 3 причин відхилення стану здоров'я, зниження темпів фізичного розвитку, виникнення патологічних процесів, що суттєво впливають на фізичну та розумову працездатність, є порушення постави у дітей шкільного віку [10]. Порушення постави і сколіоз особливо часто виникають у період значної активізації процесів росту дітей у віці 10-14 років і мають неухильну тенденцію до збільшення. Прикро, що батьки і дорослі, які оточують дитину, звертаються за допомогою лише тоді, коли добре помітні ознаки відхилень хребта від його фізіологічного положення, проявляються симптоми порушення функцій органів, що з віком може провести до інвалідності. Л.А.Страшок, вивчаючи клінічні особливості гастродуоденоденальної патології у підлітків, відзначає проблему поєднаності (синтропії) цих захворювань та їх зв'язок 3 загальними етіологічними факторами, 3 конституцією включно. Серед симптомів захворювань шлунково-кишкового тракту відзначається м'язове напруження живота, що може впливати на стан постави. 3 іншого боку, неправильна постава, нерівномірне напруження черевних м'язів гіпотетично може стати причиною дискомфорту органів черевної порожнини. Саме тому проблема реабілітації школярів, які мають поєднання порушень постави та захворювання на гастрит, є достатньо важливою $[7,8]$.

Вважаємо, що в сучасних умовах проблема порушень постави є актуальною для всіх дітей. Організм дітей і підлітків відрізняється від організму дорослих не тільки розмірами, але й особливостями будови i функціонального стану органів і систем. Процес фізичного розвитку дітей перебігає нерівномірно, періоди посиленого росту змінюються його сповільненням, змінюються енергетичні й обмінні процеси. Відбувається інтенсивне збільшення довжини та маси тіла, кісткової системи. Тому у дітей при неправильному фізичному навантаженні та недбалому ставленні до власної постави можуть виникати стійкі відхилення в розвитку хребта. Статистика підтверджує, що 27\% дітей віком від 7 до 9 років страждає від порушень постави, серед 10-14-літніх понад 40\%. Проблема порушень постави у 15-17-річних підлітків становить 33\%. Сколіоз зустрічається у 15-20\% дітей, причому у дівчат частіше, ніж у хлопців, тому що вони ведуть менш рухливий спосіб життя. Найбільш небезпечним для розвитку порушень постави вважається вік від 10 до 14 років, коли скелет ще не сформувався, а дитині доводиться частіше сидіти за уроками тощо. Цьому сприяють надлишок ваги, носіння в одній руці важких сумок вагою понад 30\% від ваги власного тіла. Друга велика проблема полягає у тривалому часі, який діти проводять перед екраном комп'ютера. Нормальна ж постава забезпечує оптимальні умови для функціонування всіх органів і систем організму. На позу впливають багато причин: емоції, ступінь розвитку мускулатури і форма хребта [4].

Мета роботи: вивчення динаміки співвідношення порушень стану хребта у дітей із захворюванням на гастрит та удосконалити комплексну програму фізичної терапії на базі санаторію “Поляна”.

\section{Методи та організація досліджень}

Ми провели спостереження у 50 дітей шкільного віку від 12 до 15 років (середній шкільний вік), з них дівчат 27 , хлопців 23, які перебували на санаторно-курортному лікуванні в санаторії "Поляна" терміном 24 дні. Для 
спостереження із направлених на оздоровлення в санаторій учнів була відібрана група з 50 дітей, у яких захворювання на гастрит поєднувалося 3 порушеннями постави. Діагноз гастрит базувався на даних клініколабораторних та інструментальних методів дослідження, які проводились за місцем проживання.

Для визначення порушення постави всім дітям, які розпочинали курс реабілітації, проводили 5 тестів: тест біля вертикальної площини, біля дзеркала на симетричність постави, тест на розташування остистих відростків на одній вертикальній лінії, тест на рівність трикутників талії, тест на симетрію кутів обох лопаток, тест на виявлення функціонального блоку прямих м'язів спини при нахилі хребта. Ступінь кіфотичної постави визначався розрахунком плечового індексу, де ширина плечей вимірювалася сантиметровою стрічкою між плечовими точками спереду, а плечова дуга між точками ззаду і перемножувалася на 100\%. Зміни у сполучній тканині визначали методом пальпації 2 і 3 пальцями зі зміщенням шкіри на спині, а також методом відтягування шкірної складки і прилеглої до неї шкірної клітковини. Для оцінки стану здоров'я та фізичної працездатності дітей використовувались функціональна проба Руф'є. Цей показник розраховується на співвідношеннях величини пульсу, зафіксованої на різних етапах відновлення після відносно невеликих навантажень. 3 цією метою діти виконували 30 присідань за 45 секунд. Пульс визначався в положенні лежачи на спині протягом 5 хвилин за 15 секунд до навантаження, а потім знову підраховувався за перші 15 секунд і останні 15 секунд протягом першої хвилини в період відновлення. Одержані результати розраховувалися за формулою. Ця проба $є$ достатньо інформативною і не потребує додаткового обладнання.

\section{Результати дослідження та їх обговорення}

У обстежених дітей виявлено порушення постави у сагітальній i фронтальній площині. У результаті проведених обстежень порушення постави виявлено у $100 \%$ хворих на гастродуоденіт, тобто у 50 дітей. Із них сутулість (збільшення грудного кіфозу i зменшення поперекового лордозу) виявлено у 21 школяра - 42,0\%, сколіоз І ступеня виявлено у 5 учнів, тобто $10 \%$, плоска спина (зменшення фізіологічних викривлень хребта) у 9 дітей - 18\%, сколіотична (асиметрична) постава - у 15 учнів - 30\%. При пальпації методом надавлювання i зміщення досліджуваної ділянки виявлена болючість шкіри справа від хребта у ділянці спинномозкових сегментів D6-D9. Усі діти, які направлялися в санаторій 3 діагнозом гастрит, на початку лікування виявляли скарги на втомлюваність, болі в ділянці шлунка, печію, нудоту, здуття живота тощо.

Перед початком реабілітаційного курсу проведено пробу Руф'є, у хворих на гастрит високий індекс працездатності не був виявлений, натомість середній

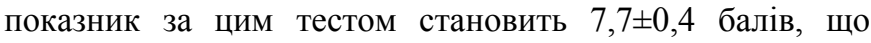
відповідає задовільній оцінці. Найнижчі показники (погано) виявлені у 9 дітей. Дані щодо цього тесту на початку і в кінці курсу наведені у таблиці.

Таблиияя

\begin{tabular}{|l|c|c|c|c|}
\hline $\begin{array}{l}\text { Порушення } \\
\text { постави }\end{array}$ & Кількість & \multicolumn{3}{|c|}{\begin{tabular}{c} 
До реабілітації \\
\hline \multicolumn{1}{|c|}{ середн. }
\end{tabular}} \\
\hline Сутулість & 21 & 2 & 6 & 6 \\
\hline Плоска спина & 9 & 1 & 2 & 2 \\
\hline $\begin{array}{l}\text { Сколіотична } \\
\text { постава }\end{array}$ & 15 & 1 & 3 & 3 \\
\hline Сколіоз & 5 & - & 1 & 1 \\
\hline Разом & 50 & 4 & 13 & 13 \\
\hline
\end{tabular}

Результати проби Руф’с

\begin{tabular}{|c|c|c|c|c|}
\hline \multicolumn{4}{|c|}{ Після реабілітації } \\
\hline низький & добре & середн. & задов. & низький \\
\hline 4 & 5 & 9 & 6 & 1 \\
\hline 1 & 2 & 4 & 2 & 1 \\
\hline 5 & 3 & 5 & 5 & 2 \\
\hline 2 & - & 2 & 2 & 1 \\
\hline 11 & 10 & 20 & 15 & 5 \\
\hline
\end{tabular}

Всі пацієнти пройшли курс відновного санаторнокурортного лікування, який включав щадно-тренуючий режим, внутрішній прийом мінеральної води Поляна Купіль, вуглекислі мінеральні ванни, лікувальну гімнастику, сегментарно-рефлекторний масаж. В комплекс лікувальної гімнастики входили спеціальні вправи, які були направлені на корекцію порушень постави та покращення функцій шлунка і пілородуоденального відділу, крово- і лімфообігу в органах черевної порожнини, зміцнення м'язів живота 3 підвищенням внутрічеревного тиску у поєднанні 3 дихальними вправами i вправами на розслаблення. Проводили сегментарно-рефлекторний масаж спини, зокрема нижньогрудних i поперекових спинномозкових сегментів, що дало можливість впливати на стан шлунка та пілородуоденальної зони, покращення функцій ЦНС,

нормалізацію секреторної і моторної діяльності шлунка, регенеративних процесів. Призначення лікувальної ходьбитеренкуру, кліматотерапії - це адаптація до психологічних і фізичних навантажень. а також відновлення працездатності. Комплекс фізичної реабілітації був спрямований на відновлення порушених механізмів адаптивної регуляції і саморегуляції на різних рівнях.

Контрольну групу становили 15 дітей такого ж віку, у яких порушення порушення постави поєднувалося 3 захворюванням на гастрит, для них у комплекс лікувальної гімнастики входили загальнорозвиваючі вправи i класичний масаж.

В результаті проведеного курсу реабілітації всіх дітей, у яких виявлене порушення постави у поєднанні 3 захворюванням на гастрит, було повторно обстежено, 
зафіксовано покращання показників як суб'єктивного, так і об'єктивного характеру. Зокрема, повторно виконана проба Руф’є показала загальне підвищення індекса працездатності до рівня добре, дистрибуція порушень постави змінилася: прояви сутулості зменшилися до 18\% (у 12 школярів), сколіозу - 6\% (у 2 школярів), плоскої спини - 8\% (у 5 школярів), сколіотичної постави - 14\% (у 8 дітей). Разом 3 тим зникли скарги на болі в ділянці епігастрію, помірне здуття живота, нудота у 89,5\% пацієнтів. Кращі показники виявлялися $\mathrm{y}$ експериментальній групі, порівняно 3 контрольною.

\section{Висновки}

1. Підсумовуючи результати спостережень за школярами, які пройшли курс поєднаної реабілітації, спрямованої на основне захворювання та порушення постави, можемо констатувати, що названі патології $є$ часто поєднаними і взаємно посилюються, погіршуючи тим самим загальний фізичний стан пацієнта.
2. Виходячи 3 таблиці, зниження працездатності більш виявлене у дітей, у яких захворювання на гастрит поєднувалося $з$ сколіотичною (асиметричною) поставою, сутулістю та сколіозом.

3. Застосування комплексу спеціальних вправ та масажу, які цілеспрямовано направлені на усунення поєднаної патології, $є$ ефективним засобом реабілітації постави та, одночасно, посилює вплив курортних факторів на функцію шлунка.

4. Санаторно-курортна реабілітації дітей, у яких порушення постави поєднується 3 захворюванням на гастрит, є доцільною та достатньо дієвою.

\section{Перспективи подальших досліджень}

Подальші дослідження передбачають вивчення віддалених результатів фізичної терапії дітей шкільного віку з порушенням постави і хворих на сколіоз І ступеня в поєднанні з захворюванням на хронічний гастрит

\section{Література}

1. Апанасенко Г.Л. Эволюция биоэнергетики и здоровья человека. - Санкт-Петербург, МГП «Петрополис», 1992. $-123 \mathrm{c}$.

2. Воскобойнікова Г.Л., Жульова С.І., Воскобойніков О.В. Методичні підходи до організації оздоровчої профілактичної роботи в загальноосвітній школі // http://www.bdpu.org/scientific_published/pedagogscs_4_2006/9.doc.

3. Котешева И.А. Нарушения осанки. Лечение и профилактика. - М. : Изд-во Эксмо, 2004. -208 с.

4. Круцевич Т.Ю., Воробьев М.И. Контроль в физическом воспитании детей, подростков и юношей. - Киев, 2005. - 195 c.

5. Милюкова И.В., Евдокимова Т.А. Лечебная гимнастика при нарушениях осанки у детей. - М. : Изд-во Эксмо; Спб.: Сова, 2003. - 128 с.

6. Профілактор Євмінова як засіб корекції порушень постави у школярів / П.Д. Плахтій, В.М. Мухін, В.В. Євмінов, І.О. Куделя. - Кам’янець-Подільський : Абетка, 2006. - 160 с.

7. Страшок Л.А. Клинические особенности гастродуоденальной патологии у детей подросткового возраста // Современная Педиатрия. - № 4 (13). - 2006. - С. 96-133.

8. Язловецкий В.С. Физическое воспитание подростков с ослабленным здоровьем. - К. : Здоров’я, $1987 .-136$ с.

\section{References}

1. Apanasenko G.L. Evolyutsiya bioenergetiki i zdorovya cheloveka. - Spb : MGP «Petropolis», 1992. - $123 \mathrm{~s}$.

2. VoskoboynIkova G.L., Zhulova S.I., VoskoboynIkov O.V. Metodichni pidhodi do organizatsiyi ozdorovchoyi profilaktichnoyi roboti v zagalnoosvitniy shkoli //http://www.bdpu.org/scientific_published/pedagogscs_4_2006/9.doc.

3. Kotesheva I.A. Narusheniya osanki. Lechenie i profilaktika. - M. : Izd-vo Eksmo, 2004. - 208 s.

4. Krutsevich T.Yu., Vorobev M.I. Kontrol v fizicheskom vospitanii detey, podrostkov i yunoshey. - Kiev, $2005 .-195$ s.

5. Milyukova I.V., Evdokimova T.A. Lechebnaya gimnastika pri narusheniyah osanki u detey. - M.: Izd-vo Eksmo; Spb.: Sova, 2003. - $128 \mathrm{~s}$.

6. ProfIlaktor Evminova yak zasib korektsiyi porushen postavi u shkolyariv / P.D.Plahtiy, V.M.Muhin, V.V.Evminov, I.O.Kudelya. - Kam'yanets-Podilskiy : Abetka, 2006. - 160 s.

7. Strashok L.A. Klinicheskie osobennosti gastroduodenalnoy patologii u detey podrostkovogo vozrasta // Sovremennaya Pediatriya. - \# 4 (13). - 2006. - S. 96-133.

8. Yazlovetskiy V.S. Fizicheskoe vospitanie podrostkov s oslablennyim zdorovem. - K. : Zdorov'ya, 1987. - 136 s. 
Физическая терапия детей школьного возраста с нарушением осанки у сочетании заболеванием на хронический гастрит

Филак Я.Ф., Филак Ф.Г.

ГВУЗ «Ужгородский национальный университет»

Цель работы - изучение динамики соотношения нарушений позвоночника у детей, больных гастритом, которые проходили оздоровительный курс на базе санатория "Поляна".

Задачи - определение приемов ы средств физической реабилитации детей школьного возраста, у которых нарушения осанки сочетаются 3 заболеванием гастритом. Использованы такие методы исследования, как тесты на выявление нарушений осанки, проба Руфье, клинические обследование в начале и в конце проведенного оздоровительного курса. Изучалось влияние комплексного подхода к реабилитации детей, наблюдались положительные изменения со стороны обеих патологий. Обследовано 50 детей школьного возраста, у которых заболевание гастритом сочеталось с сутулосью, плоской спиной, сколиотической осанкой, сколиозом. Под влиянием реабилитационных мероприятий прослеживаются положительные изменения как в клинических проявлениях основного заболевания, так и в коррекции осанки.

Ключевые слова: осанка, гастрит, физическая реабилитация, массаж, дети, проба Руфье.

\section{Physical therapy of school-age children with postural impairment in combination with chronic gastritis}

Filak J.F., Filak F.G. Uzhhorod National University

The aim of invetstigation is to study the dynamics of correlatio of disfunction of the vertebri condition among the children with the gastritis disease who hos passed the healing course on the basis of sanatorium "Polyana". The main task is to define methods and means of physical rehabilitation of the scoolchildren who have the dispenctions of carriage together with the gastritis disease. The follourig methods of investigation are used : the test aimed to define the exposure of violations of carriage, test of Rufyes, clinical inspections of the beginning and the end of the conducted healing treatment. The impact of the complex approach to the rehabilitation of children is studied, the positive changes from the side of both patologies are observed. 50 children have been the object of investigation, who have gastritis disseases combined with a stoop, flat back, skoliosis carriage, skoliosis. Under the influence of rehabilitation means positive changes are observed both in clinical displays of the main disease and in the correction of carriage.

Key words: carriage, gastritis, phisical rehabilitation, massage, children, Rufye's test.

\section{Відомості про авторів}

Філак Ярослав Феліксович - кандидат наук 3 фізичного виховання та спорту, доцент, в.о. завідувача кафедри фізичної реабілітації ДВНЗ «Ужгородський національний університет»; 88001, м. Ужгород, вул. І. Франка 1.

Філак Фелікс Георгійович - кандидат медичних наук, доцент, доцент кафедри основ медицини ДВНЗ «Ужгородський національний університет»; 88001, м. Ужгород, вул. І. Франка 1. 